\title{
Kognitiivsete ja metakognitiivsete õpistrateegiate toetamine tehnoloogiaga tõhustatud keeleõppes
}

\author{
Katrin Saks ${ }^{\mathrm{a} 1}$, Äli Leijen ${ }^{\mathrm{a}}$ \\ a Tartu Ülikooli haridusteaduste instituut
}

\begin{abstract}
Annotatsioon
Hea võõrkeeleoskus on globaliseeruvas maailmas eduka toimetuleku eeldus. On leitud, et õppija keeleoskus on seotud tema keeleõppestrateegiate kasutusega, seetõttu peetakse õpistrateegiate mõõtmist üheks enim levinud keeleõppe efektiivsuse hindamise meetodiks. Kuigi strateegiate kasutamise oskus ja harjumused on väga individuaalsed ning kujunevad välja pikema aja jooksul, on uuringud näidanud, et õppijaid on võimalik suunata kasutama efektiivsemaid õpistrateegiaid, toetades nende õpitegevust. Praeguse uurimuse eesmärk on töötada varasemate uurimistulemuste põhjal välja sekkumistegevused, millega toetatakse kognitiivseid ja metakognitiivseid keeleõppestrateegiaid tehnoloogiaga tõhustatud võõrkeelekursusel, ning katsetada nende efektiivsust. Sekkumine hõlmab spetsiaalseid õpiülesandeid, mille sooritamist toetatakse märguannetega. Andmed pärinevad nii ainetestist kui ka eesti keele jaoks kohandatud enesekohaste küsimustikega Est-SILLi, MSQLi ja SRL-SRSi eel- ja järeltestist, mis tehti neljakuusel erialase inglise keele kursusel. Uurimistulemused näitavad, et varasemates uurimustes välja pakutud kognitiivsete ja metakognitiivsete õpistrateegiate kombineeritud toetamine märguannetega annab positiivseid tulemusi nii keeleõppestrateegiate ja eneseregulatsiooni toetamisel kui ka aineteadmiste omandamisel.
\end{abstract}

Võtmesõnad: keeleõppestrateegiad, eneseregulatsioon, aineteadmised, segaõppe kursus, enesekohane küsimustik

\section{Sissejuhatus}

Õpitehnoloogia laialdane kasutamine eri õpisituatsioonides on toonud õppijate jaoks kaasa järjest kasvava vajaduse reguleerida oma õpitegevust

1 Haridusteaduste instituut, Tartu Ülikool, Salme 1a, 50103 Tartu; katrin.saks@ut.ee 
(Bannert \& Reimann, 2012) ning arendada endas iseseisvust ja autonoomiat, et õpitegevust kontrollida ja juhtida. Kui traditsioonilises koolitunnis võib õppija jääda passiivseks teadmiste vastuvõtjaks, siis õppimine tehnoloogiaga tõhustatud keskkondades eeldab õppijapoolset autonoomiat, võimet analüüsida ja reguleerida oma õpitegevust. Paljud uurijad on näidanud, et akadeemilise edukuse ja enesereguleeritava õpioskuse vahel valitseb tugev positiivne seos (Dabbagh \& Kitsantas, 2005; Schunk \& Zimmerman, 1994). See osutab sellele, et edukatel õppijatel on ka head enesereguleeritavad õpioskused, eriti õpitegevuse planeerimisel, eelteadmiste aktiveerimisel ja seostamisel (Azevedo, 2004). Ometi ei evi õppijad just sageli piisavat eneseregulatsioonivõimet, mis omakorda takistab neil saavutamast rahuldavaid akadeemilisi õpitulemusi (Kiewra, 2002; Lee, Lim, \& Grabowski, 2010). Sarnast enesereguleeritavate õpioskuste defitsiiti on täheldatud ka keeleõppijate puhul (Benson, 2011). Õppija keeleõppestrateegiate kasutust peetakse üheks võimaluseks hinnata tema keeleõppe edukust (Hsiao \& Oxford, 2002), kuna õpistrateegiate kasutamine on seotud keeleoskuse tasemega ning võimaldab tõhustada õpitegevust ja toetada õppija iseseisvust ja eneseregulatsiooni (Wong, 2011).

Eelneva põhjal saab välja tuua, et enesereguleeritavad õpioskused ja sobivad keeleõppestrateegiad on keeleõppes akadeemilise edukuse eeldus. Samas näitavad mitmed uurimistulemused, et enesereguleeritavad õpioskused on ühed kõige raskemini omandatavad õpioskused (Benson, 2011; Mcmahon \& Oliver, 2001). Seetõttu on vaja leida tõhusaim viis óppijate enesereguleeritavate õpioskuste toetamiseks ja neid ka vastavalt õpetada. Praeguse uurimuse eesmärk on tutvustada ja hinnata efektiivsete keeleõppestrateegiate ja enesereguleeritavate õpioskuste arendamise mudelit keeleõppe kontekstis. Mudeli loomisel lähtuti Oxfordi (1990) keeleõppestrateegiate teoreetilisest raamistikust ja Pintrichi (2000) eneseregulatsiooniteooriast, millest antakse järgnevalt ülevaade.

\section{Teoreetiline raamistik}

Paljud konstruktivistlikud õpiteooriad rõhutavad eneseregulatsiooni olulisust õpiprotsessis. Strateegilise õppimise teooria (Weinstein, 1994) keskendub õppijale kui aktiivsele ja pühendunud indiviidile, kes töötleb informatsiooni ja konstrueerib uusi teadmisi. See mudel asetab õppija ópiprotsessi keskmesse ja ümbritseb ta kolme interaktiivse komponendiga, mis kirjeldavad edukat ópiprotsessi: oskused, tahe ja eneseregulatsioon. Oskused viitavad õppija tegevustele ja mõtlemisprotsessidele, mis 
on seotud võtmekontseptsioonide ja -protsesside äratundmisega. Tahe osutab indiviidi suhtumisele õpitegevusse, uue informatsiooni vastuvõtmisele, soovile keskenduda ja pingutada ning murele oma soorituse pärast. Eneseregulatsioon on metakognitiivne protsess, mis väljendab õppija võimekust juhtida oma õpiprotsesse, eelkõige seda, kuidas planeerida, jälgida ja hinnata oma õpitegevust, ning valmisolekut võtta vastutus oma õpiprotsessi ja selle tulemuslikkuse eest. Lähtudes neist kolmest komponendist, osutavad õpistrateegiad õppija mõtetele, käitumisviisidele, uskumustele ja emotsioonidele, mis toetavad teadmiste omandamist, õpitust arusaamist ning hiljem uute teadmiste ja oskuste rakendamist (Tsai, 2009). See üldine raamistik kattub tänapäevase keeleõppe käsitlusega, mis toetab kommunikatiivse keeleõppe ja metakognitsiooni põhimõtteid. Järgmises alapeatükis antakse ülevaade keeleõppestrateegiate ja eneseregulatsiooni põhiolemusest.

\section{Õppimise ja õpistrateegiate mudelid}

Aastate jooksul on loodud erinevaid keeleõppestrateegiate klassifikatsioone (O’Malley \& Chamot, 2002; Rubin, 1975; Stern, 1975), mis kõik on andnud oma panuse Oxfordi (1990) kuuest strateegiagrupist koosnevasse taksonoomiasse. Õpistrateegiad on õppija tegevused, mis on vajalikud aktiivseks, teadlikuks, eesmärgipäraseks ja keskendunud õppimiseks. Nende toel on õppijal võimalik arendada suuremat vilumust, õpiautonoomiat ja eneseregulatsiooni (Hsiao \& Oxford, 2002). Oxford ja Crookall väidavad, et keeleõppestrateegiate kasutamine võimaldab õppijatel arendada enesejuhitavaid õpioskusi ja olla paremini orienteeritud probleemile. Õpistrateegiad toetavad õpiprotsessi nii otseselt kui ka kaudselt. Õpistrateegiate kasutamine ei ole alati teadlik tegevus ning sageli on seda raske kõrvalt jälgida, kuid neid on võimalik õpetada teadlikult kasutama (Oxford \& Crookall, 1989). Oxfordi keeleõppestrateegiate süsteemi peetakse komplekssemaks ja detailsemaks kui tema eelkäijate omi (Jones, 1998). Oxford jagab keeleõppestrateegiad kahte suurde rühma, eristades otseseid ja kaudseid strateegiaid (tabel 1). Otsesed strateegiad, mis hõlmavad kognitiivseid, mälu- ja kompensatsioonistrateegiaid, osalevad otseselt sihtkeele omandamise protsessis. Kaudsed strateegiad - metakognitiivsed, afektiivsed ja sotsiaalsed strateegiad - pakuvad keeleõppe protsessis kaudset tuge, näiteks tegevuse planeerimisel, koostöö ja suhtlusvõimaluste ärakasutamisel. Kuigi Oxford eristab mälu- ja kompensatsioonistrateegiaid kognitiivsetest õpistrateegiatest, peetakse kognitiivseteks strateegiateks kõiki selliseid õpitegevusi, mille käigus õppija hangib, säilitab ning taaskasutab oma teadmisi ja 
oskusi. Need strateegiad sisaldavad informatsiooni hankimist, selekteerimist ja organiseerimist, õpitud materjali kordamist, uue seostamist varem õpituga, informatsiooni säilitamist ning taaskasutamist (McKeachie, 1994). Oxfordi taksonoomias on aga mälustrateegiad eraldi välja toodud, kuna nende kasutussagedus on oluliselt suurem algajate keeleõppijate puhul, mistõttu saab kasutussageduse põhjal määrata õppija keeleõppekogemust.

Tabel 1. Keeleõppestrateegiate klassifikatsioon Oxfordi (1990) järgi

\begin{tabular}{|c|c|c|}
\hline \multirow{3}{*}{$\begin{array}{l}\text { Otsesed strateegiad } \\
\text { on vahetult seotud } \\
\text { õpitava keele ja } \\
\text { õpiprotsessiga }\end{array}$} & \multirow{3}{*}{$\begin{array}{l}\text { Mälustrateegiad aitavad } \\
\text { salvestada informatsiooni } \\
\text { pikaajalises mälus ja } \\
\text { seda taastada suhtlus- } \\
\text { olukordade tarbeks }\end{array}$} & 1. Mentaalsete kujutluspiltide loomine \\
\hline & & $\begin{array}{l}\text { 2. Kujutluspiltide ja helide } \\
\text { rakendamine }\end{array}$ \\
\hline & & 3. Materjali korrastamine \\
\hline & \multirow{4}{*}{$\begin{array}{l}\text { Kognitiivsed stra- } \\
\text { teegiad võimaldavad } \\
\text { luua ja korrastada } \\
\text { mõttemustreid, vastu } \\
\text { võtta sõnumeid ja neid } \\
\text { sihtkeeles koostada }\end{array}$} & 1. Harjutamine \\
\hline & & $\begin{array}{l}\text { 2. Sõnumite vastuvõtmine ja } \\
\text { koostamine }\end{array}$ \\
\hline & & 3. Analüüsimine ja arutlemine \\
\hline & & 4. Mõttemustrite loomine \\
\hline & \multirow{2}{*}{$\begin{array}{l}\text { Kompensatsioonistra- } \\
\text { teegiad on vajalikud, et } \\
\text { ületada teadmiste lünki } \\
\text { sihtkeeles }\end{array}$} & 1. Olemasoleva info põhjal järeldamine \\
\hline & & $\begin{array}{l}\text { 2. Teadmiste lünklikkusest tulenevate } \\
\text { piirangute ületamine rääkimisel ja } \\
\text { kirjutamisel }\end{array}$ \\
\hline \multirow{9}{*}{$\begin{array}{l}\text { Kaudsed stra- } \\
\text { teegiad pakuvad } \\
\text { kaudset tuge } \\
\text { keeleõppes, nt pla- } \\
\text { neerimine, koostöö } \\
\text { ja suhtlusvõimaluste } \\
\text { otsimine }\end{array}$} & \multirow{3}{*}{$\begin{array}{l}\text { Metakognitiivsed } \\
\text { strateegiad aitavad } \\
\text { õppijal võtta kontrolli oma } \\
\text { õpitegevuse planeerimise, } \\
\text { juhtimise ja hindamise üle }\end{array}$} & 1. Õpitegevusele keskendumine \\
\hline & & $\begin{array}{l}\text { 2. Õpitegevuse korraldamine ja } \\
\text { planeerimine }\end{array}$ \\
\hline & & 3. Õpitegevuse hindamine \\
\hline & \multirow{3}{*}{$\begin{array}{l}\text { Afektiivsed strateegiad } \\
\text { võimaldavad õppijal } \\
\text { kontrollida oma tundeid, } \\
\text { motivatsiooni ja suhtu- } \\
\text { mist keeleõppesse }\end{array}$} & 1. Ärevustunde vähendamine \\
\hline & & 2. Enda julgustamine \\
\hline & & $\begin{array}{l}\text { 3. Oma emotsioonide taseme } \\
\text { jälgimine }\end{array}$ \\
\hline & \multirow{3}{*}{$\begin{array}{l}\text { Sotsiaalsed strateegiad } \\
\text { on vajalikud selleks, et } \\
\text { suhelda teiste keele- } \\
\text { kasutajatega }\end{array}$} & 1. Küsimuste esitamine \\
\hline & & 2. Koostöö tegemine \\
\hline & & 3. Kaaslaste toetamine \\
\hline
\end{tabular}


Metakognitsiooni tähtsust on keeleõppe kontekstis küll sageli rõhutatud (Chamot, 2005; Victori \& Lockhart, 1995), kuid tihti on see jäänud selgelt defineerimata. Selleks, et hinnata õppijate metakognitiivsete strateegiate kasutamist ja nende eneseregulatsiooni taset üldisemalt, on oluline mõista selle konstrukti sisu ja komponente ning komponentidevahelist interaktsiooni.

Enesereguleeritava õppimise kohta on esitatud palju definitsioone ja teooriaid, mis võimaldavad käsitleda selles kontekstis ette tulevaid probleeme. Ühe esimese ja sealjuures fundamentaalseima definitsiooni esitas Bandura (1986), kes ühendas enesereguleeritava õppimise oma sotsiaal-kognitiivse teooriaga inimkäitumisest. Bandura kirjeldab eneseregulatsiooni kui välise keskkonna mõjutamise protsessi, kus on tähtsal kohal enesejälgimine ja -hindamine ning oma tegevusele reageerimine. Inspireerituna Bandura töödest, defineerib Zimmerman (1986) enesereguleeritavat óppimist kui protsessi, kus õppijad aktiveerivad ja säilitavad oma kognitiivseid tegevus- ja käitumismustreid, et saavutada õpieesmärgid. Winne (1996) rõhutab aga enesereguleeritava óppimise metakognitiivset perspektiivi, nimetades enesereguleeritavat óppimist metakognitiivselt juhitud käitumiseks, mille puhul reguleerib õppija oma kognitiivsete strateegiate ja taktikate kasutamist. Pintrich lähtub oma töödes Zimmermani teooriast. Tema defineerib enesereguleeritavat oppimist kui aktiivset konstruktiivset protsessi, kus õppijad seavad endale õppimiseks eesmärgid ja seejärel püüavad jälgida, reguleerida ning kontrollida oma kognitsiooni, motivatsiooni ja käitumist (Pintrich, 2000). Kõik eespool nimetatud teooriad lähtuvad aga ühisest seisukohast, et enesereguleeritav õppimine on aktiivne ja konstruktiivne protsess, kus õppijad reguleerivad oma kognitiivseid, metakognitiivseid, motivatsiooni-, tahte- ja käitumisprotsesse õpitegevuse käigus (Winters, Greene, \& Costich, 2008).

\section{Õppijate enesereguleeritavate õpistrateegiate toetamine}

Piisavate enesereguleeritavate õpioskuste omandamist ja sel viisil paremate akadeemiliste tulemuste saavutamist (Dabbagh \& Kitsantas, 2005; Leijen, Lam, Wildschut, \& Simons, 2009; Schunk \& Zimmerman, 1994) ei saa pidada enesestmõistetavaks. Neid oskusi tuleb õpetada ning nende kasutamist ja edasiarendamist toetada kogu õpiprotsessi vältel. See aga võib osutuda õpetajate ja kursuste loojate jaoks keeruliseks ülesandeks. Üks selle artikli eesmärke on välja selgitada, millised empiirilistes uurimustes kirjeldatud sekkumisviisid on eneseregulatsiooni toetamise seisukohalt kõige tõhusamad. Järgnevalt antakse ülevaade uurimustest, milles on kirjeldatud kõige tõhusamaid sekkumisviise. 
Eri autorid on kirjeldanud mitmeid efektiivseid eneseregulatsiooni toetamise viise alates eneseregulatsiooni toetavatest mehhanismidest õppijale kohandatud e-õppe süsteemides (Chen, 2009) kuni meelitavate mobiilisõnumite (Goh, Seet, \& Chen, 2012) ja põhjalike treeningprogrammideni (Bannert \& Reimann, 2012). Tuginedes uuringutele, mille eesmärk on toetada enesereguleeritavat õppimist, võib eristada kolme efektiivset sekkumise põhiprintsiipi: 1) enesereguleeritavate õpistrateegiate õpetamine peab olema lõimitud aineõppesse ja olema konkreetse ainekursuse osa; 2) enesereguleeritavate õpistrateegiate rakendamise tingimusi ja nende kasulikkust tuleb õppijatele selgitada, sest muidu võivad õppijad sattuda segadusse ja tunda end häirituna (selle vältimiseks soovitatakse näidata ja selgitada, kuidas enesereguleeritavad oskused toetavad nende õpitegevust); 3) õppijatele tuleks jätta piisavalt aega harjutamiseks, et enesereguleeritavad õpistrateegiad ja -oskused saaksid omandatud ja muutuksid automaatseks (Bannert \& Reimann, 2012).

Eneseregulatsiooni toetamiseks on mitmeid viise. Siinses artiklis kirjeldatava sekkumise väljatöötamisel lähtuti Hannafini, Landi ja Oliveri (1999) käsitlusest, kus eristatakse nelja tüüpi toetust. Kontseptuaalne toetus (conceptual scaffolding) aitab õppijail mõista aine sisu ja eri kontseptsioonide seotust ning juhib õppija tähelepanu olulisimatele mõistetele. Metakognitiivne toetus (metacognitive scaffolding) on suunatud individuaalse õpiprotsessi juhtimisega seotud protsessidele. See mõjutab õppija mõtteid ja reflektiivset tegevust (nt harjutused ja märguanded oma tegevuse jälgimiseks ja refleksiooniks). Protseduuriline toetus (procedural scaffolding) näitab, kuidas kasutada olemasolevaid ressursse ja vahendeid seatud eesmärkide saavutamiseks. Strateegiline toetus (strategic scaffolding) hõlmab alternatiivset lähenemist õpitegevustele, toetades analüüsi, planeerimist, strateegilisi ja taktikalisi otsustusi (Hannafin et al., 1999).

Varasemad uurimused on näidanud, et kõige tõhusam õppija eneseregulatsiooni toetus on kombineeritud metakognitiivne toetus. Häid tulemusi on empiiriliste uurimuste kohaselt andnud märguannete (prompting) kombineeritud toetamine näiteks õpiprotokollidega (Berthold, Nückles, \& Renkl, 2007), kognitiivsete strateegiatega, sealhulgas kirjutamisstrateegiate ja enesereguleeritavate strateegiatega (Brunstein \& Glaser, 2011), ning eneseküsitluse mudeliga IMPROVE (Kramarski \& Gutman, 2006; Kramarski \& Michalsky, 2009, 2010). Need uurimused näitasid, et märguannetega toetamine stimuleeris õppijate kognitiivsete ja metakognitiivsete õpistrateegiate kasutamist. Metakognitiivne toetus võimaldas tõhustada mitmeid eneseregulatsiooni aspekte, sealhulgas õpitegevuse jälgimist, strateegiakasutust ja õpihuvi. Samuti selgus, et paremad õpitulemused 
olid nendes õpperühmades, kes said õppetöö käigus kognitiivseid märguandeid kombineeritult metakognitiivsete märguannetega. Seega võib väita, et kognitiivsed ja metakognitiivsed õpistrateegiad ei ole sõltumatud, vaid täiendavad üksteist; metakognitiivsed strateegiad kontrollivad ja reguleerivad kognitiivsete strateegiate kasutamist.

Selle artikli teoreetilise lähtekoha moodustab kirjanduse ülevaate põhjal kujunenud teadmus kõige tõhusamate kognitiivsete ja metakognitiivsete ópistrateegiate toetamise viisidest. Sellele tuginedes loodi mudel, mis toetab nende strateegiate kasutust võõrkeele segaõppe kursusel (blended learning). Mudel koosneb neljast märguannetega varustatud õpiülesandest (Saks \& Leijen, 2014) ja seda rakendati turismi inglise keele segaõppe kursusel. Eesmärk oli välja selgitada, kas ja kuidas muutub õppijate keeleóppestrateegiate ja enesereguleeritavate õpistrateegiate kasutus ning kas ja kuidas paranevad õppijate aineteadmised sellise sekkumise korral, kus kasutatakse märguannetega varustatud õpiülesandeid.

\section{Metoodika}

\section{Sekkumise väljatöötamine}

Võttes aluseks Oxfordi (1990) keeleõppestrateegiate teoreetilise käsitluse ja Pintrichi (2000) enesereguleeritava õppimise käsitluse, loodi mudel, et toetada õppijate kognitiivseid ja metakognitiivseid õpistrateegiaid turismi inglise keele segaõppe kursusel. Pintrich (2000) eristab nelja eneseregulatsiooni mõjuvaldkonda: kognitsiooni, motivatsiooni ja afekti, käitumist ning konteksti. Selle artikli aluseks olevas uuringus keskenduti kahele valdkonnale, milleks on kognitsioon ja käitumine. Kognitiivseid ja metakognitiivseid strateegiaid toetati õppeprotsessi käigus korraga, kuna varasemad uuringud on näidanud, et nende kahe kombineeritud toetamine annab parimaid tulemusi nii eneseregulatsiooni arendamisel kui ka aineteadmiste omandamisel (Berthold et al., 2007; Brunstein \& Glaser, 2011; Lee et al., 2010).

Selle kursuse tarbeks loodi neli spetsiaalset keeleõppeülesannet eesmärgiga toetada õppijate kognitiivsete keeleõppestrateegiate ja metakognitiivsete õpistrateegiate kasutamist. Ülesannete loomisel sooviti kasutada maksimaalselt ära digitaalse õpikeskkonna (Moodle) tehnilisi ja didaktilisi võimalusi. Erilist tähelepanu pöörati õppijate aktiivsele keelekasutusele turismivaldkonnast võetud reaaleluliste probleemide lahendamisel. Peale nende nelja ülesande sisaldas kursus rohkesti tavapäraseid sõnavara-, lugemis- ja suhtlusülesandeid, mida samuti toetati suuliste ja kirjalike 
märguannetega nii tunnis kui ka veebikeskkonnas. Märguanded esitati õppijatele suunavate küsimuste kujul. Nende eesmärk oli julgustada õppijaid teadlikumalt ja oskuslikumalt kasutama kognitiivseid õpistrateegiaid (nt võrdlema, analüüsima, kokkuvõtteid tegema), kuid ka oma tegevust paremini planeerima, jälgima ja hindama. Näiteks kuvati ülesande alustamise ja planeerimise faasis õppijatele õpikeskkonnas aken järgmiste küsimustega: While planning your work ask yourself the following questions - What am I supposed to learn? What prior knowledge will help me with this task? What should I do first? What should I look for in this task? How much time do I have to complete this? In what direction do I want my thinking to take me? Sarnaseid suunavaid küsimusi esitati õppijatele ka tunnis suuliselt, et toetada nende kognitiivsete ja metakognitiivsete õpistrateegiate tõhusamat kasutamist.

Esimene ülesanne, mis tuli õppijatel kursuse käigus sooritada, oli õpiplaani koostamine. See algas suulise aruteluga klassis, kus õppijatel tuli suunavate küsimuste toel arutleda selle üle, mis on nende õpieesmärgid sellel kursusel, millised on nende vajadused ja ootused, võttes arvesse enda keeleoskust ja -taset. Samuti paluti õppijatel mõelda nende õpistrateegiate peale, mida nad on seni harjunud keele õppimisel kasutama, ning jõuda seisukohale, milline hindamine ja tagasisidestamine toetavad nende õpiprotsessi kõige paremini. Kuna selline tegevus ei olnud õppijate jaoks tavapärane, siis tuli neid toetada ja julgustada oma mõtteid, sealhulgas ootusi ja hirme, väljendama. Selleks kasutati suulisi märguandeid suunavate küsimuste kujul. Samal ajal selgitati õppijatele, miks on oluline seada eesmärke ja planeerida oma tegevust enne kursuse ja õpiülesannete algust. Pärast suulist arutelu klassis koostasid õppijad Moodle'i keskkonnas oma õpipäeviku esimese sissekande, kus nad samade toetavate küsimuste ja märguannete põhjal panid kirja oma õpiplaani kogu kursuse jaoks. Õppijatele selgitati, et ópiplaan ei ole lóplik dokument ning nad võivad alati pöörduda selle juurde tagasi, et seda täpsustada ja parandada. Digitaalse õpipäeviku mõte oli anda õppijatele võimalus jäädvustada oma mõtted ja tunded kogu õpiprotsessi vältel. See andis ka õpetajale informatsiooni õppija edasijõudmise, tema probleemide ning jälgimis- ja refleksioonioskuse kohta. Ühtlasi võimaldas see anda õppijale tagasisidet, vastata tema küsimustele ja toetada tema õpiprotsessi.

Teine ülesanne oli essee kirjutamine oma kodumakonna turismiobjektide põhjal. Põhjus, miks see ülesanne mudelisse lisati, oli võimalus siduda see erinevate kognitiivsete ja metakognitiivsete strateegiatega. $\mathrm{Ka}$ seda ülesannet alustati klassis ühise aruteluga, kus õppijatele selgitati ülesande sisu, aktiveeriti nende eelteadmised ning tekitati huvi teemakohase 
info otsimise vastu. Essee kirjutamine jäi iseseisvaks ülesandeks tundidevahelisel ajal. Sel perioodil said õppijad tuge Moodle'i keskkonnas esitatud kirjalike märguannete näol. Ülesande sooritamise ajal suunati õppijaid mõtlema mitmesugustele kognitiivsetele ja metakognitiivsetele tegevustele, mis olid olulised ülesande edukaks sooritamiseks. Nende hulka kuulusid eesmärgi püstitamine, kirjutamisplaani koostamine, aja planeerimine, info otsimine, info kriitiline hindamine, analüüsimine, ideede selge formuleerimine, kokkuvõtte kirjutamine, oma tegevuse jälgimine ja hindamine. Järeltegevusena julgustati õppijaid klassis oma kirjutamiskogemust reflekteerima ehk arutlema selle üle, mis probleemid tekkisid protsessi käigus, kuidas need ületati, kas ja millist tuge oleksid nad lisaks vajanud. Ühtlasi paluti õppijatel anda hinnang oma tööle.

Kolmas ja neljas ülesanne olid paaritööd ja järgisid sarnast struktuuri. Ülesannete käigus tuli õppijatel sooritada järgmised tegevused: tegevuse eesmärgistamine, planeerimine ja ülesannete jagamine, info otsimine ühe maailma vähem külastatava sihtkoha (ülesanne 3) ja kolme turismiettevõtte (ülesanne 4) kohta, materjali kriitiline hindamine, võrdleminevastandamine, analüüsimine, ideede formuleerimine, oma mõttemustrite korrastamine, kokkuvõtte kirjutamine, suulise ettekande koostamine ja selle ettekandmine, oma õpitegevuse jälgimine, hindamine ja reflekteerimine. Nende ülesannete väärtus seisnes võimaluses seostada keeleõpe reaaleluliste olukordadega. Ülesannete käigus tuli õppijatel lahendada autentseid probleeme, kasutades autentseid materjale, ning kaitsta oma valikuid ja otsuseid. Samamoodi nagu eelmiste ülesannete puhul, alustati ka praegusel juhul tööd ühise aruteluga klassis, et tekitada teema vastu huvi ning aktiveerida varasemad ainealased ja metakognitiivsed teadmised. Kuna tegemist oli paaritöödega ja õppijad pidid seadma eesmärke ja planeerima oma tegevust ühiselt, oli selle juures väga oluline rakendada nii sotsiaalseid kui ka aktiivse keelekasutuse strateegiaid. Suulised ettekanded, millega need ülesanded lõpetati, võimaldasid õppijatel reflekteerida kogu õpiprotsessi ning anda hinnang oma tööle nii individuaalselt kui ka paarina.

Mudeli väljatöötamisel pöörati erilist tähelepanu kognitiivsetele ja metakognitiivsetele märguannetele, millega varustati kõik õpiülesanded. Varasemad uuringud on näidanud, et õpistrateegiate kasutuse efektiivsus ja õpitulemused on otseselt seotud mõningate enesereguleeritavate tegevuste kasutussagedusega (Azevedo, 2005; Winters et al., 2008), seetõttu kasutati sarnast märguannete struktuuri ja loogikat kogu kursuse vältel. Mudelit ja loodud toe tõhusust kontrolliti uuringu käigus turismi ja ettevõtluse eriala esimese kursuse üliõpilaste peal. 


\section{Valim}

Valimisse kuulus 28 esimese kursuse üliõpilast, kes osalesid turismi inglise keele kursusel. Kursus kestis neli kuud, selle aja jooksul oli 40 kontakttundi. 28st valimisse kuulunud inimesest 5 olid mehed (17,9\%) ja 23 naised $(82,1 \%)$. Üliõpilaste keskmine vanus oli 20,2 aastat $(S D=3,4)$. Varem olid nad oppinud inglise keelt keskmiselt kümme aastat $(M=10,4 ; S D=2,1)$. Nende keskmine inglise keele riigieksami (B2-tase) tulemus oli 75,1 punkti 100st $(S D=13,8)$.

\section{Andmete kogumine ja analïïs}

Selleks, et hinnata õppijate kognitiivsete ja metakognitiivsete õpistrateegiate kasutamist ning nende muutumist sekkumise tagajärjel, koguti respondentidelt andmeid kolme enesekohase küsimustikuga.

Keeleõppestrateegiate kasutamist uuriti küsimustikuga Est-SILL, mis on Oxfordi SILLi (1990) põhjal Eesti keeleõppijate jaoks kohandatud ja valideeritud küsimustik (Saks, Leijen, Õun, \& Täht, 2015c; Saks, Leijen, \& Täht, 2015b). Est-SILL koosneb 17 väitest, mida vastajad hindavad Likerttüüpi skaalal 1st 5ni, kõrgemad punktid viitavad sagedasemale strateegiate kasutusele. Est-SILLi moodustavad kuus faktorit: aktiivse keelekasutuse strateegiad (väljendavad õppija algatatud keelekasutust reaalelulistes olukordades ning kujutavad endast kombinatsiooni Oxfordi kognitiivsetest ja sotsiaalsetest ópistrateegiatest), metakognitiivsed strateegiad (väljendavad õpitegevuse planeerimist, jälgimist ja hindamist), sotsiaalsed strateegiad (kasutatakse abi küsimiseks ja andmiseks õpisituatsioonis), kompensatsioonistrateegiad (nende abil ületatakse lünki teadmistes), mälustrateegiad (mälutehnilised võtted, mis aitavad paremini meelde jätta uut materjali) ja seostamisstrateegiad (kasutatakse varem õpitu aktiveerimiseks ja seostamiseks uue õpitava materjaliga). Küsimustik on valideeritud, selle aluseks oleva mudeli headuse hindamise indeksid on head $\left(\chi^{2}=\right.$ 222,40; $d f=104$; $\mathrm{CMIN} / \mathrm{DF}=2,14 ; \mathrm{CFI}=0,91$; RMSEA $=0,07$ ) (Saks et al., 2015b).

Õppijate enesereguleeritavate õpistrateegiate mõõtmiseks kasutati kaht enesekohast küsimustikku: MSLQd (Pintrich, Smith, Garcia, \& McKeachie, 1991) ja SRL-SRSi (Toering, Elferink-Gemser, Jonker, van Heuvelen, \& Visscher, 2012). Eesti keelde tõlgitud ja kohandatud küsimustik MSLQ koosneb kahest osast - motivatsiooni ja strateegiate mõõdikust -, kus vastajad hindavad esitatud väiteid Likert-tüüpi skaalal 1st 7ni, kõrgemad punktid näitavad kõrgemat eneseregulatsiooni taset (vt lisaks Saks, Leijen, Edovald, \& Õun, 2015a). Motivatsiooni mõõdikus on 
27 väidet, mis jagunevad kuude faktorisse: sisemine ja väline motivatsioon, ülesande väärtustamine, kontroll õpiuskumuste üle, enesetõhusus ja testipinge. Mõõdiku mudeli headuse indeksid on aktsepteeritavad $\left(\chi^{2}=\right.$ 875,28 ; $d f=309$; CMIN/DF $=2,83$; CFI = 0,85; RMSEA = 0,07). Strateegiate mõõdikus on 34 väidet, mis jagunevad seitsmesse faktorisse: harjutamine, organiseerimine, seostamisstrateegiad, jõupingutuse reguleerimine, metakognitiivne eneseregulatsioon, aeg ja õpikeskkond ning kaaslastelt õppimine. Mõõdiku mudeli headuse indeksid on järgmised: $\chi^{2}=1095,87$; $d f=507 ; \mathrm{CMIN} / \mathrm{DF}=2,16$; CFI $=0,85 ; \mathrm{RMSEA}=0,06$.

SRL-SRS on samuti tõlgitud ja kohandatud Eesti õppija jaoks. Selle kuude faktorisse jaotunud 33 väidet hindavad vastajad Likert-tüüpi skaalal 1st 5ni, kõrgemad punktid näitavad kõrgemat eneseregulatsiooni taset. Faktoranalüüsi tulemusena moodustunud faktorid on planeerimine, õpitegevuse jälgimine, hindamine, jõupingutuse reguleerimine, ajaplaneerimine ja enesetõhusus. SRL-SRSi mudeli headuse indeksid on head: $\chi^{2}=983,47 ; d f=480 ; \mathrm{CMIN} / \mathrm{DF}=2,05 ; \mathrm{CFI}=0,89 ; \mathrm{RMSEA}=0,05$.

Põhjus, miks otsustati kasutada kaht eneseregulatsiooni mõõdikut, seisnes nende erinevas lähenemises eneseregulatsiooni mõõtmisele. Kui MSLQ sisaldab eneseregulatsiooni mõõtmiseks üht strateegiate alajaotust (metakognitiivset eneseregulatsiooni), siis SRL-SRSis vaadeldakse täpsemalt kolme põhilist enesereguleeritavat tegevust (planeerimist, õpitegevuse jälgimist ja hindamist) eraldi. Sarnaste alajaotuste kasutamine ja võrdlemine võimaldavad detailsemalt jälgida ja mõtestada õppijate õpitegevust, samuti põhjalikumalt uurida märguannete toimimist ja nende tulemuslikkust. Kõik metakognitsiooni ja metakognitiivsete tegevuste planeerimise, jälgimise ja hindamise - omavahelised Pearsoni korrelatsiooniindeksid on kolme mõõdiku põhjal keskmise tugevusega (tabel 2), mistõttu võib väita, et eri mõõdikuid kasutades saab mõõta eneseregulatsiooni omavahel seotud konstrukte.

Aineteadmiste paranemist mõõdeti ainetestiga, mille koostas artikli esimene autor ainekursuse sisu põhjal. Test sisaldas kombineeritud lugemis-, kirjutamis- ja sõnavaraülesandeid, mille sooritamist toetas nii kognitiivsete kui ka metakognitiivsete keeleõppestrateegiate kasutamine. Kuna tegemist oli erialase keelekursusega, tuli üliõpilastel ainetestis selgitada inglise keeles mitmeid termineid. Samuti tuli neil inglise keeles võrrelda eri majutusasutusi, tuues välja nende sarnasused ja erinevused. Parimaks näiteks kombineeritud ülesande kohta on kirjutamisülesanne: üliõpilastel tuli koostada vastuskiri, mis põhines loetud tekstil ning eeldas sõnavara ja kirja koostamise põhimõtete tundmist ning üldisi ainespetsiifilisi ja keeleteadmisi. Andmeid koguti eel- ja järeltestiga. Nii eel- kui ka järeltest sisal- 
dasid 13 ülesannet, kuid järeltestis olid need pisut mahukamad ja eeldasid põhjalikumaid vastuseid. Testi vastuseid hinnati punktidega, mis hiljem arvutati ümber protsentideks.

Tabel 2. Metakognitsiooni mõõtvate skaalade korrelatsiooniindeksid

\begin{tabular}{c|c|c|c|c|c}
\hline & $\begin{array}{c}\text { Meta- } \\
\text { kognitsioon, } \\
\text { Est-SILL }\end{array}$ & $\begin{array}{c}\text { Planeerimine, } \\
\text { SRL-SRS }\end{array}$ & $\begin{array}{c}\text { Jälgimine, } \\
\text { SRL-SRS }\end{array}$ & $\begin{array}{c}\text { Hindamine, } \\
\text { SRL-SRS }\end{array}$ & $\begin{array}{c}\text { Meta- } \\
\text { kognitsioon, } \\
\text { MSLQ }\end{array}$ \\
\hline $\begin{array}{c}\text { Meta- } \\
\text { kognitsioon, } \\
\text { Est-SILL }\end{array}$ & 1 & 0,30 & 0,25 & 0,30 & $0,48^{* *}$ \\
\cline { 2 - 6 } & 28 & 0,12 & 0,20 & 0,12 & 0,01 \\
\hline $\begin{array}{c}\text { Planeerimine, } \\
\text { SRL-SRS }\end{array}$ & 0,30 & 1 & $0,56^{* *}$ & 0,24 & $0,38^{*}$ \\
\cline { 2 - 6 } & 0,12 & 28 & 0,00 & 0,23 & 0,04 \\
\cline { 2 - 6 } & 28 & 28 & 28 & 28 & 28 \\
\hline \multirow{2}{*}{$\begin{array}{c}\text { Jälgimine, } \\
\text { SRL-SRS }\end{array}$} & 0,25 & $0,56^{* *}$ & 1 & 0,42 & $0,38^{*}$ \\
\cline { 2 - 6 } & 0,20 & 0,00 & 28 & 0,03 & 0,05 \\
\cline { 2 - 6 } & 28 & 28 & 28 & 28 & 28 \\
\hline \multirow{2}{*}{$\begin{array}{c}\text { Hindamine, } \\
\text { SRL-SRS }\end{array}$} & 0,30 & 0,24 & $0,42^{*}$ & 1 & $0,39^{*}$ \\
\cline { 2 - 6 } & 0,12 & 0,23 & 0,03 & 28 & 0,0 \\
\cline { 2 - 6 } & 28 & 28 & 28 & 28 & 28 \\
\hline \multirow{2}{*}{$\begin{array}{c}\text { Meta- } \\
\text { kognitsioon, }\end{array}$} & $0,48^{* *}$ & $0,38^{*}$ & $0,38^{*}$ & $0,39^{*}$ & 1 \\
\cline { 2 - 6 } & 0,01 & 0,04 & 0,05 & 0,0 & 28 \\
\hline
\end{tabular}

Märkused. ${ }^{*}$ - korrelatsioon 0,05 olulisuse nivool. ${ }^{* *}$ - korrelatsioon 0,01 olulisuse nivool.

\section{Tulemused}

\section{Muutused õppijate keeleõppestrateegiate kasutuses}

Et vastata uurimisküsimusele, kas ja kuidas muutus õppijate keeleõppestrateegiate kasutus sellise sekkumise tulemusena, kus kasutati märguannetega varustatud õpiülesandeid, võrreldi kuue keeleõppestrateegiate skaala eel- ja järeltesti keskmisi väärtusi. Õppijate keeleõppestrateegiate kasutussageduse muutust neli kuud kestnud kursuse järel hinnati sõltuvate kogumite t-testiga. T-testi tulemustest annab ülevaate tabel 3, millest on 
näha märkimisväärseim strateegiate kasutuse kasv aktiivse keelekasutuse, kompensatsioonistrateegiate ja sotsiaalsete strateegiate rühmas.

Tabel 3. Muutus õppijate $(N=28)$ keeleõppestrateegiate kasutuses eel- ja järeltesti põhjal (mõõdetud Est-SILLiga)

\begin{tabular}{l|c|c|c|c|c}
\hline Strateegiate rühm & $\begin{array}{c}\text { Eeltest } \\
\boldsymbol{M}(S D)\end{array}$ & $\begin{array}{c}\text { Järeltest } \\
\boldsymbol{M}(S D)\end{array}$ & $\boldsymbol{t}$ & $\boldsymbol{d f}$ & $\boldsymbol{p}$ \\
\hline Aktiivne keelekasutus & $3,25(0,75)$ & $3,94(0,61)$ & $-4,93$ & 27 & 0,000 \\
\hline Metakognitsioon & $3,69(0,67)$ & $4,08(0,71)$ & $-2,89$ & 27 & 0,007 \\
\hline Sotsiaalsed strateegiad & $3,65(0,64)$ & $4,07(0,74)$ & $-3,07$ & 27 & 0,005 \\
\hline Kompensatsioonistrateegiad & $3,77(0,81)$ & $4,23(0,69)$ & $-3,69$ & 27 & 0,001 \\
\hline Mälustrateegiad & $1,57(0,56)$ & $1,86(0,86)$ & $-1,89$ & 27 & 0,069 \\
\hline Seostamisstrateegiad & $3,29(0,84)$ & $3,73(0,89)$ & $-2,29$ & 27 & 0,030 \\
\hline
\end{tabular}

Märkus. $p<0,05$.

Ainus rühm, kus olulist strateegiate kasutuse kasvu ei ole, on mälustrateegiad. See on igati ootuspärane, kuna tegemist on edasijõudnud keeleõppijatega. Mälustrateegiate aktiivsem kasutus on omasem algajale keeleõppijale (Oxford, 1990).

Need tulemused näitavad, et märguannetega varustatud õpiülesanded, mis toetavad kognitiivseid ja metakognitiivseid õpistrateegiaid, soodustavad õppijate kõrgema taseme keeleõppestrateegiate kasutust. Kõige enam suurenes keeleõppijate aktiivse keelekasutuse ja kompensatsioonistrateegiate kasutussagedus. See tuleneb tõenäoliselt kommunikatiivse keeleõppemetoodika kasutamisest, rohketest suhtlusülesannetest tunnis ja võimalusest väljendada end nii kõnes kui ka kirjas.

\section{Muutused õppijate enesereguleeritavate õpistrateegiate kasutuses}

Et vastata uurimisküsimusele, kas ja kuidas muutus õppijate enesereguleeritavate õpistrateegiate kasutus sellise sekkumise tulemusena, kus kasutati märguannetega varustatud õpiülesandeid, võrreldi MSLQ ja SRL-SRSi skaala eel- ja järeltesti keskmisi väärtusi.

Sõltuvate kogumite t-testi tulemused (tabel 4) annavad tunnistust sekkumise positiivsest mõjust enesereguleeritavatele õpistrateegiatele. Märkimisväärselt paranesid õppijate sisemine motivatsioon ja kontroll oma ópiuskumuste üle. 
Tabel 4. Muutus õppijate $(N=28)$ enesereguleeritavate strateegiate kasutuses eel- ja järeltesti põhjal

\begin{tabular}{|c|c|c|c|c|c|c|}
\hline Mõõdik & Faktor & $\begin{array}{l}\text { Eeltest } \\
M(S D)\end{array}$ & $\begin{array}{c}\text { Järeltest } \\
M(S D)\end{array}$ & $T$ & $d f$ & $p$ \\
\hline \multirow{6}{*}{$\begin{array}{l}\text { MSLQ, } \\
\text { moti- } \\
\text { vatsioon }\end{array}$} & Sisemine motivatsioon & $5,14(1,0)$ & $5,51(0,88)$ & $-2,32$ & 27 & 0,028 \\
\hline & Väline motivatsioon & $4,99(1,15)$ & $5,05(1,35)$ & $-0,36$ & 27 & 0,720 \\
\hline & Ülesande väärtustamine & $5,86(0,67)$ & $5,85(0,72)$ & 0,04 & 27 & 0,972 \\
\hline & Kontroll õpiuskumuste üle & $5,59(1,2)$ & $6,06(0,77)$ & $-2,57$ & 27 & 0,016 \\
\hline & Enesetõhusus & $4,86(1,09)$ & $4,78(0,92)$ & 0,51 & 27 & 0,612 \\
\hline & Testipinge & $4,01(1,42)$ & $3,96(1,4)$ & 0,22 & 27 & 0,829 \\
\hline \multirow{7}{*}{$\begin{array}{l}\text { MSLQ, } \\
\text { stratee- } \\
\text { giad }\end{array}$} & Harjutamine & $4,62(0,89)$ & $5,08(0,81)$ & $-2,91$ & 27 & 0,007 \\
\hline & Organiseerimine & $3,43(1,2)$ & $3,69(1,2)$ & $-1,04$ & 27 & 0,307 \\
\hline & Seostamisstrateegiad & $4,58(0,79)$ & $4,89(0,88)$ & $-2,43$ & 27 & 0,022 \\
\hline & Jõupingutuse reguleerimine & $2,88(0,98)$ & $3,44(1,18)$ & $-2,79$ & 27 & 0,009 \\
\hline & $\begin{array}{l}\text { Metakognitiivne } \\
\text { eneseregulatsioon }\end{array}$ & $4,45(0,92)$ & $5,0(0,87)$ & $-2,91$ & 27 & 0,007 \\
\hline & Aeg ja õpikeskkond & $5,07(1,11)$ & $4,5(0,93)$ & 0,47 & 27 & 0,641 \\
\hline & Kaaslastelt õppimine & $4,36(1,29)$ & $4,66(1,16)$ & $-1,99$ & 27 & 0,055 \\
\hline \multirow[t]{6}{*}{ SRL-SRS } & Planeerimine & $2,77(1,0)$ & $3,05(0,93)$ & $-2,25$ & 27 & 0,033 \\
\hline & Jälgimine & $3,48(0,45)$ & $3,48(0,74)$ & $-0,05$ & 27 & 0,962 \\
\hline & Hindamine & $3,9(0,56)$ & $4,1(0,59)$ & $-2,07$ & 27 & 0,048 \\
\hline & Ajaplaneerimine & $3,28(0,55)$ & $3,27(0,85)$ & 0,06 & 27 & 0,954 \\
\hline & Jõupingutuse reguleerimine & $3,36(0,47)$ & $3,62(0,83)$ & $-2,11$ & 27 & 0,045 \\
\hline & Enesetõhusus & $3,62(0,48)$ & $3,79(0,63)$ & $-1,85$ & 27 & 0,075 \\
\hline
\end{tabular}

Märkus. $p<0,05$.

Ka strateegiakasutuses ilmnesid mitmed olulised positiivsed muutused. Kõige enam paranes harjutamisstrateegiate ja metakognitiivsete eneseregulatsioonistrateegiate kasutus, samuti jõupingutuse reguleerimine. Toeringu SRL-SRSi mõõdiku paralleelne kasutamine võimaldas uurida metakognitiivsete õpistrateegiate muutust detailsemalt, kuna selle mõõdiku puhul olid metakognitiivsed tegevused - planeerimine, jälgimine ja hindamine - üksteisest eraldatud. T-testi tulemustest selguski, et sekkumine oli 
kõige enam toetanud õppijate planeerimis- ja hindamisstrateegiate paranemist, kuid mitte õpitegevuse jälgimist.

Seega näitasid tulemused, et metakognitiivsete õpistrateegiate kombineerimine kognitiivsetega toetab märguannetega varustatud õpiülesannete kaudu kõige enam õppijate metakognitiivset eneseregulatsiooni, eelkõige nende planeerimis- ja hindamistegevust. Ühtlasi toetab see õppijate kontrolli oma õpiuskumuste üle, aidates kaasa õppija sisemise motivatsiooni kasvule. Selleks, et toetada õppijat õpitegevuse jälgimise faasis, on tõenäoliselt vajalik otsesem toetus ka suuliste märguannete ja õpetaja suunava tegevuse vormis.

\section{Muutused õppijate aineteadmistes}

Et vastata uurimisküsimusele, kas ja kuidas paranesid õppijate aineteadmised sellise sekkumise tulemusena, kus kasutati märguannetega õpiülesandeid, võrreldi ainetesti eel- ja järeltesti tulemusi. Ootuspäraselt näitas sõltuvate kogumite t-test õppijate aineteadmiste märkimisväärset paranemist: eeltesti $M=29,57, S D=16,27$, järeltesti $M=71,64, S D=11,02$; $t(27)=-16,86 ; p=0,000$.

Tulemused viitavad sellele, et loodud ülesanded koos kognitiivset ja metakognitiivset õpitegevust toetavate märguannetega aitavad kaasa ainega seotud teadmiste ja oskuste omandamisele ning toetavad keeleõppijate eneseväljendusoskust. Eriti selgelt avaldus see ülesannetes, kus õppijatel tuli värskelt omandatud erialast sõnavara kasutades selgitada turismivaldkonna termineid, kõrvutada valdkonnaga seotud objekte ja tegevusi, tuua välja nende sarnasusi ja erinevusi ning koostada ametlik vastus kaebekirjale. Ainetestis sisaldunud kombineeritud ülesanded näitasid ilmekalt õppijate suutlikkust oma uusi teadmisi ja oskusi rakendada ning neid keeleliselt väljendada.

\section{Arutelu}

Paljud uurijad on nentinud, et eneseregulatsiooni on väga keeruline õpetada. Siinse uuringu eesmärk oli näidata, et õppijate eneseregulatsiooni on siiski võimalik toetada ja arendada, kui selleks kasutatakse tõhusaimat sekkumist. Keeleõppe kontekstis ei ole autoritele teadaolevalt eneseregulatsiooni ja efektiivsete keeleõppestrateegiate toetamise mudelit varem välja töötatud, mistõttu oligi selle töö eesmärk luua keeleõppe tarbeks selline sekkumine, mis toetaks õppijate kognitiivseid ja metakognitiivseid protsesse, ning seda katsetada. Sekkumise väljatöötamisel võeti 
arvesse varasemate uuringute tulemusi. Uuringud on näidanud, et kognitiivsete ja metakognitiivsete õpistrateegiate kasutus suureneb kõige enam siis, kui neid toetatakse märguannete abil (nt Brunstein \& Glaser, 2011; Kramarski \& Michalsky, 2010; Lee et al., 2010). Selle artikli aluseks olevas uuringus kasutati märguandeid õppijate õpitegevuse toetamiseks nelja õpiülesande sooritamisel. Peale veebipõhiste märguannete toetati õpilasi klassis ka suuliste märguannetega. Muutusi õppijate õpistrateegiate kasutuses mõõdeti kolme eesti keelde tõlgitud ja kohandatud enesekohase küsimustiku ja ainetestiga eel- ja järeltesti vormis.

Nii nagu ilmnes Nash-Ditzeli (2010) korraldatud uuringust, kus keskenduti spetsiifilisemalt küll lugemisstrateegiate ja eneseregulatsiooni toetamisele, selgus ka praegusest uuringust, et keeleõppestrateegiate kasutussagedus paraneb märguannete toel tuntavalt. Keeleõppestrateegiate analüüsis ilmnesid positiivsed tulemused kõigis olulisimates õpistrateegiates. Suurimaid muutusi, mis toimusid aktiivse keelekasutuse, sotsiaalsete ja kompensatsioonistrateegiate rühmades, võib seletada kommunikatiivse keeleõppe metoodika kasutamisega ja selliste õpiülesannetega, mis eeldasid aktiivset suhtlust ja eneseväljendust nii kõnes kui ka kirjas. Ainus strateegiarühm, kus olulist muutust ei täheldatud, olid mälustrateegiad. Seda võib pidada ootuspäraseks, kuna teooriast on teada, et mälustrateegiaid kasutavad valdavalt algajad keeleõppijad (O’Malley \& Chamot, 2002; Oxford, 1990). Õpingute edenedes nende mälustrateegiate osakaal väheneb ja nende asemel kasutatakse teisi, kõrgema taseme strateegiaid. See omakorda toetab õppijate enesereguleeritavate õpioskuste arendamist (Oxford \& Crookall, 1989), mis meie uuringus väljendus metakognitiivsete strateegiate märkimisväärses kasvus. Arvestades selle uuringu valimit, kelleks olid keskmiselt 10,4 aastat inglise keelt õppinud esmakursuslased ja kelle üldine inglise keele tase riigieksami tulemuste põhjal oli hea ( $M=75,14$ punkti 100st), oli edasijõudnute keeleõppestrateegiate (s.t aktiivse keelekasutuse strateegiate, sotsiaalsete, metakognitsiooni-, kompensatsiooni- ja seostamisstrateegiate) kasutuse paranemine sellisel määral ootuspärane.

Metakognitiivsete õpistrateegiate õpetamist peetakse praktikas üheks raskemini saavutatavaks ülesandeks (Benson, 2011; Mcmahon \& Oliver, 2001). Ometi on sekkumisviisid, kus õppija kognitiivsete ja metakognitiivsete õpistrateegiate toetamiseks kasutatakse märguandeid, andnud valdavalt positiivseid tulemusi (Askell-Williams, Lawson, \& Skrzypiec, 2012; Bannert \& Reimann, 2012; Kauffman, Zhao, \& Yang, 2011). Niisamuti olid selle uuringu tulemused metakognitsiooni toetamisel positiivsed. MSLQga mõõdetud motivatsiooniskaalade t-testis ilmnesid positiivsed tulemused 
sisemisel motivatsioonil ja kontrollil oma õpiuskumuste üle. Mõlemat peetakse oluliseks ka heade õpitulemuste ennustajana (Khatib, 2010). Kuigi sekkumiseks loodud ópiülesanded olid küllaltki detailselt planeeritud, oli ka õppijatel võimalik otsustada mitmete oluliste nüansside üle. See andis neile võimaluse kaasa rääkida õpiprotsessi kohandamises nende vajaduste ja ootuste järgi ning ühtlasi toetas see nende õpimotivatsiooni säilimist. MSLQ strateegiaskaalade t-test tõi esile strateegiate kasutuse olulise kasvu neljas rühmas. Nii nagu Est-SILLiga mõõdetud seostamisstrateegiad, andsid need ka MSLQs positiivse tulemuse. Kui keeleõppes väljenduvad seostamisstrateegiad keeleteadmiste kombineeritud kasutamises, siis MSLQ seab fookusesse õppija üldised teadmised ja maailmapildi. Arvestades, et erialase inglise keele õpingud baseeruvad varem õpitud üldkeele teadmistel, siis on edukaks hakkamasaamiseks väga tähtis osata aktiveerida ja ära kasutada varem omandatut, seostada uut materjali vanaga ja selle baasil luua uus teadmus (Conteh-Morgan, 2002). Eelteadmiste aktiveerimise ja seostamise oskust läheb tarvis ka õppija eneseregulatsiooni planeerimise faasis (Pintrich, 2000). Sarnaselt Nash-Ditzeli (2010) tulemustega saab ka praegusel juhul rääkida kognitiivsete ópistrateegiate paranemisest märguannete toel. Kognitiivsete ehk harjutamisstrateegiate kasutussageduse märkimisväärne suurenemine räägib tavapäraste õpiülesannete oskusliku sooritamise kasuks. Need strateegiad väljendavad õppija oskust töötada iseseisvalt õppematerjalidega, korrata varem õpitut ning leida informatsiooni, et täiendada kursuse materjale.

Vaatlusaluse kursuse jaoks loodud õpiülesanded, mis sisaldasid eraldi märguandeid planeerimis-, jälgimis- ja hindamisfaasis, keskendusid põhiliselt õppijate metakognitiivsete ja kognitiivsete õpistrateegiate toetamisele. T-testi tulemused väljendasid metakognitiivsete strateegiate kasutuse paranemist nii Est-SILLi, MSLQ kui ka SRL-SRSi mõõdikutes. Huvitav on aga asjaolu, et kui vaadata metakognitsiooni alamkonstrukte - planeerimist, jälgimist ja hindamist - eraldi SRL-SRSi mõõdikus, siis ilmneb, et strateegiate kasutuse määr paranes vaid planeerimis- ja hindamisfaasis. Erinevalt paljudest uuringutest, mis keskendusid kõigile enesereguleeritavatele tegevustele või ainult jälgimisfaasile ja selle toetamisele ning kus õnnestus näidata jälgimisstrateegiate paranemist (nt Kramarski \& Gutman, 2006; Mäeots, 2014), siinse uuringu põhjal sellist muutust ei täheldatud. Seda saab mõneti selgitada töökorraldusega, mis kaasnes sekkumiseks loodud õpiülesannetega. Nimelt alustati kõigi ülesannetega ühiselt tunnis, kui tutvuti ülesande juhendiga ning asuti planeerima edasist tegevust (sh tööjaotus, ajaplaneerimine). Seda toetasid õppejõu suunavad küsimused ja soovitused. Planeerimist toetavad märguanded ilmusid õppijale ka veebi- 
keskkonnas, kus ta asus tööle iseseisvalt või koos paarilisega. Ülesande sisuline osa jäi õppijatel teha iseseisvalt tundidevahelisel ajal. Eeldati, et sel ajal jälgivad nad ise oma õpiülesande sooritamist. Seda toetati samal ajal küll veebikeskkonnas ilmuvate märguannetega, kuid tunnis õppejõud õpiülesande sooritamise jälgimist ei kontrollinud ega suunanud. Asjaolu, et õpitegevust jälgiti vaid veebikeskkonnas õppijate iseseisva töö käigus, võib olla põhjus, miks jälgimine sekkumise tulemusena ei paranenud. Ometi on jälgimine väga oluline kogu eneseregulatsiooni kontekstis, kuna see tagab enesereguleeritavate strateegiate sagedasema ja järjepidevama kasutuse ning õpitulemuste paranemise (Hodges, 2005; Mcmahon \& Oliver, 2001). Oma tegevuse hindamiseks oli õppijatel mitu võimalust, sealhulgas suuline refleksioon järgnevas tunnis ja kirjalik refleksioon veebikeskkonnas (õpipäevikus). Selline õppija mitmekordne toetamine nii suuliste kui ka kirjalike märguannetega tagas planeerimis- ja hindamisstrateegiate märkimisväärse paranemise võrreldes jälgimisega. Sama moodi nagu Azevedo uurimus (2005), kinnitasid ka siinsed uurimistulemused, et märguannete kasutamine annab paremaid tulemusi ópistrateegiate toetamisel siis, kui seda teha nii tunnis ühiselt kui ka veebikeskkonnas iseseisvalt töötades ning asjakohaseid tegevusi võimalikult sageli korrates.

Nii nagu ilmnes Kramarski ja Michalsky (2010), Kauffmani ja tema kolleegide (2011) ning paljude teiste sarnastest uurimustest, näitavad praegused tulemused, et kognitiivsete ja metakognitiivsete õpistrateegiate kasutuse kasvades paranevad õppijate õpitulemused ka võõrkeelekursusel. Ainetesti tulemused, mis paranesid kõigi eespool nimetatutega võrreldes kõige enam, viitavad sellele, et loodud ülesanded koos kognitiivset ja metakognitiivset õpitegevust toetavate märguannetega aitavad kaasa aineteadmiste omandamisele. Seega võib väita samamoodi nagu Kramarski ja Michalsky (2009), Quintana, Zhang ja Krajcik (2005) jpt, et kognitiivset ja metakognitiivset tuge pakkuvad märguanded on üks viis õpitulemusi parandada.

Kokkuvõtteks võib öelda, et varasemates uurimustes välja pakutud kognitiivsete ja metakognitiivsete ópistrateegiate kombineeritud toetamine (nt Berthold et al., 2007; Brunstein \& Glaser, 2011) märguannetega (Kramarski \& Michalsky, 2009; Lee et al., 2010) andis ka praegusel juhul positiivseid tulemusi nii keeleõppestrateegiate ja eneseregulatsiooni toetamisel kui ka aineteadmiste omandamisel. Edasised uuringud peaksid aga enam keskenduma enesejälgimisele õpiprotsessis dubleerituna nii veebikeskkonnas kui ka tunnisituatsioonis. 


\section{Tänuavaldus}

Artikli valmimist toetas Euroopa sotsiaalfondi haridus- ja kasvatusteaduste doktorikool (1.2.0401.09-0070).

\section{Kasutatud kirjandus}

Askell-Williams, H., Lawson, M. J., \& Skrzypiec, G. (2012). Scaffolding cognitive and metacognitive strategy instruction in regular class lessons. Instructional Science, 40(2), 413-443. doi: http://dx.doi.org/10.1007/s11251-011-9182-5

Azevedo, T. (2004). Does training on self-regulated learning facilitate students' learning with hypermedia? Journal of Educational Psychology, 96(3), 523-535. doi: http://dx.doi.org/10.1037/0022-0663.96.3.523

Azevedo, T. (2005). Using hypermedia as a metacognitive tool for enhancing student learning? The role of self-regulated learning. Educational Psychologist, 40(4), 199-209. doi: http://dx.doi.org/10.1207/s15326985ep4004_2

Bandura, A. (1986). Social foundations of thought and action: A social cognitive theory. Englewood Cliffs, NJ: Prentice Hall.

Bannert, M., \& Reimann, P. (2012). Supporting self-regulated hypermedia learning through prompts. Instructional Science, 40(1), 193-211. doi: http://dx.doi.org/10.1007/s11251-011-9167-4

Benson, P. (2011). Teaching and researching autonomy (2nd ed.). London: Pearson Education.

Berthold, K., Nückles, M., \& Renkl, A. (2007). Do learning protocols support learning strategies and outcomes? The role of cognitive and metacognitive prompts. Learning and Instruction, 17(5), 564-577. doi: http://dx.doi.org/10.1016/j.learninstruc.2007.09.007

Brunstein, J. C., \& Glaser, C. (2011). Testing a path-analytic mediation model of how self-regulated writing strategies improve fourth graders' composition skills: A randomized controlled trial. Journal of Educational Psychology, 103(4), 922-938. doi: http://dx.doi.org/10.1037/a0024622

Chamot, A. U. (2005). Language learning strategy instruction: Current issues and research. Annual Review of Applied Linguistics, 25, 112-130. doi: http://dx.doi.org/10.1017/S0267190505000061

Chen, C.-M. (2009). Personalized E-learning system with self-regulated learning assisted mechanisms for promoting learning performance. Expert Systems with Applications, 36(5), 8816-8829. doi: http://dx.doi.org/10.1016/j.eswa.2008.11.026

Conteh-Morgan, M. (2002). Connecting the dots: Limited English proficiency, second language learning theories, and information literacy instruction. The Journal of Academic Librarianship, 28(4), 191-197. doi: http://dx.doi.org/10.1016/S0099-1333(02)00282-3

Dabbagh, N., \& Kitsantas, A. (2005). Using web-based pedagogical tools as scaffolds for self-regulated learning. Instructional Science, 33(5-6), 513-540.

doi: http://dx.doi.org/10.1007/s11251-005-1278-3 
Goh, T.-T., Seet, B.-C., \& Chen, N.-S. (2012). The impact of persuasive SMS on students' self-regulated learning. British Journal of Educational Technology, 43(4), 624-640. doi: http://dx.doi.org/10.1111/j.1467-8535.2011.01236.x

Hannafin, M., Land, S., \& Oliver, K. (1999). Open learning environments: Foundations, methods, and models. In C. M. Reigeluth (Ed.), Instructional-design theories and models: A new paradigm of instructional theory (Vol. 2, pp. 115-140). Mahwah, NJ: Lawrence Erlbaum.

Hodges, C. B. (2005). Self-regulation in web-based courses: A review and the need for research. The Quarterly Review of Distance Education, 6(4), 375-383.

Hsiao, T.-Y., \& Oxford, R. L. (2002). Comparing theories of language learning strategies: A confirmatory factor analysis. The Modern Language Journal, 86(3), 368383. doi: http://dx.doi.org/10.1111/1540-4781.00155

Jones, S. (1998). Learning styles and learning strategies: Towards learner independence. Forum for Modern Language Studies, 34(2), 114-129. doi: http://dx.doi.org/10.1093/fmls/34.2.114

Kauffman, D. F., Zhao, R., \& Yang, Y.-S. (2011). Effects of online note taking formats and self-monitoring prompts on learning from online text: Using technology to enhance self-regulated learning. Contemporary Educational Technology, 36(4), 313-322. doi: http://dx.doi.org/10.1016/j.cedpsych.2011.04.001

Khatib, S. A. A. (2010). Meta-cognitive self-regulated learning and motivational beliefs as predictors of college students' performance. International Journal for Research in Education, 27, 57-72.

Kiewra, K. A. (2002). How classroom teachers can help students learn and teach them how to learn. Theory into Practice, 41(2), 71-80. doi: http://dx.doi.org/10.1207/s15430421tip4102_3

Kramarski, B., \& Gutman, M. (2006). How can self-regulated learning be supported in mathematical E-learning environments? Journal of Computer Assisted Learning, 22(1), 24-33. doi: http://dx.doi.org/10.1111/j.1365-2729.2006.00157.x

Kramarski, B., \& Michalsky, T. (2009). Investigating preservice teachers' professional growth in self-regulated learning environments. Journal of Educational Psychology, 101(1), 161-175. doi: http://dx.doi.org/10.1037/a0013101

Kramarski, B., \& Michalsky, T. (2010). Preparing preservice teachers for self-regulated learning in the context of technological pedagogical content knowledge. Learning and Instruction, 20(5), 434-447. doi: http://dx.doi.org/10.1016/j.learninstruc.2009.05.003

Lee, H. W., Lim, K. Y., \& Grabowski, B. L. (2010). Improving self-regulation, learning strategy use, and achievement with metacognitive feedback. Educational Technology Research and Development, 58(6), 629-648. doi: http://dx.doi.org/10.1007/s11423-010-9153-6

Leijen, Ä., Lam, I., Wildschut, L., \& Simons, P. R.-J. (2009). Difficulties teachers report about students' reflection: Lessons learned from dance education. Teaching in Higher Education, 14(3), 315-326.

doi: http://dx.doi.org/10.1080/13562510902898882

McKeachie, W. J. (1994). Teaching tips: Strategies, research, and theory for college and university teachers (9th ed.). Lexington, MA: D. C. Heath and Company. 
Mcmahon, M., \& Oliver, R. (2001). Promoting self-regulated learning in an on-line environment. In C. Montgomerie \& J. Viteli (Eds.), Proceedings of World Conference on Educational Multimedia, Hypermedia and Telecommunications 2001 (pp. 1299-1305). Chesapeake, VA: AACE. Retrieved from http://ro.ecu.edu.au/cgi/viewcontent.cgi?article=5815\&context=ecuworks.

Mäeots, M. (2014). Inquiry-based learning in a web-based learning environment: A theoretical framework of inquiry-based learning processes (Doctoral dissertation). Retrieved from http:/dspace.utlib.ee/dspace/bitstream/handle/10062/43719/ maeots_mario.pdf? sequence $=1$.

Nash-Ditzel, S. (2010). Metacognitive reading strategies can improve self-regulation. Journal of College Reading and Learning, 40(2), 45-63. doi: http://dx.doi.org/10.1080/10790195.2010.10850330

O'Malley, J. M., \& Chamot, A. U. (2002). Learning strategies in second language acquisition (4th ed.). Cambridge: Cambridge University Press.

Oxford, R. L. (1990). Language learning strategies: What every teacher should know. New York, NY: Newbury House/Harper \& Row.

Oxford, R. L., \& Crookall, D. (1989). Research on language learning strategies: Methods, findings, and instructional issues. The Modern Language Journal, 73(4), 404-419. doi: http://dx.doi.org/10.1111/j.1540-4781.1989.tb05321.x

Pintrich, P. R. (2000). The role of goal orientation in self-regulated learning. In M. Boekaerts, P. R. Pintrich, \& M. Zeidner (Eds.), Handbook of self-regulation (pp. 531-566). San Diego etc.: Academic Press.

doi: http://dx.doi.org/10.1016/b978-012109890-2/50043-3

Pintrich, P., Smith, D. A. F., Garcia, T., \& McKeachie, W. J. (1991). A manual for the use of the Motivated Strategies for Learning Questionnaire (MSLQ). Ann Arbor, MI: National Center for Research to Improve Postsecondary Teaching and Learning.

Quintana, C., Zhang, M., \& Krajcik, J. (2005). A framework for supporting metacognitive aspects of online inquiry through software-based scaffolding. Educational Psychologist, 40(4), 235-244. doi: http://dx.doi.org/10.1207/s15326985ep4004_5

Rubin, J. (1975). What the "good language learner” can teach us. TESOL Quarterly, 9(1), 41-51. doi: http://dx.doi.org/10.2307/3586011

Saks, K., \& Leijen, Ä. (2014). Model for supporting cognitive and metacognitive strategies in technology enhanced language learning. The 22nd International Conference on Computers in Education, 630-639.

Saks, K., Leijen, Ä., Edovald, T., \& Õun, K. (2015a). Cross-cultural adaptation and psychometric properties of the Estonian version of MSLQ. Procedia - Social and Behavioral Sciences, 191, 597-604. doi: http://dx.doi.org/10.1016/j.sbspro.2015.04.278

Saks, K., Leijen, Ä., \& Täht, K. (2015b). Developing a model for measuring Estonian EFL learners' language learning strategies. INTED 2015 Proceedings (pp. 1241-1247).

Saks, K., Leijen, Ä., Õun, K., \& Täht, K. (2015c). Factorial structure of SILL revisited: Adaptation of SILL for Estonian EFL learners. In H. Metslang, M. Langemets, \& M.-M. Sepper (Eds.), Eesti Rakenduslingvistika Ühingu aastaraamat (pp. 241-261). Tallinn: Eesti Rakenduslingvistika Ühing. doi: http://dx.doi.org/10.5128/erya11.15 
Schunk, D. H., \& Zimmerman, B. J. (1994). Self-regulation of learning and performance: Issues and educational applications. Hillsdale, NJ: Erlbaum.

Stern, H. H. (1975). What can we learn from the good language learner? Canadian Modern Language Review, 31, 304-318.

Zimmerman, B. J. (1986). Becoming a self-regulated learner: Which are the key subprocesses? Contemporary Educational Psychology, 11(4), 307-313. doi: http://dx.doi.org/10.1016/0361-476X(86)90027-5

Toering, T., Elferink-Gemser, M. T., Jonker, L., van Heuvelen, M. J. G., \& Visscher, C. (2012). Measuring self-regulation in a learning context: Reliability and validity of the Self-Regulation of Learning Self-Report Scale (SRL-SRS). International Journal of Sport and Exercise Psychology, 10(1), 24-38. doi: http://dx.doi.org/10.1080/1612197X.2012.645132

Tsai, M.-J. (2009). The model of strategic e-learning: Understanding and evaluating student e-learning from metacognitive perspectives. Educational Technology \& Society, 12(1), 34-48.

Victori, M., \& Lockhart, W. (1995). Enhancing metacognition in self-directed language learning. System, 23(2), 223-234. doi: http://dx.doi.org/10.1016/0346-251x(95)00010-h

Weinstein, C. E. (1994). Strategic learning/strategic teaching: Flip sides of a coin. In P. R. Pintrich, D. R. Brown, \& C. E. Weinstein (Eds.), Student motivation, cognition, and learning: Essays in honor of Wilbert J. McKeachie (pp. 257-273). Hillsdale, NJ: Lawrence Erlbaum.

Winne, P. H. (1996). A metacognitive view of individual differences in self-regulated learning. Learning and Individual Differences, 8(4), 327-353. doi: http://dx.doi.org/10.1016/S1041-6080(96)90022-9

Winters, F. I., Greene, J. A., \& Costich, C. M. (2008). Self-regulation of learning within computer-based learning environments: A critical analysis. Educational Psychology Review, 20(4), 429-444. doi: http://dx.doi.org/10.1007/s10648-008-9080-9

Wong, M. S.-L. (2011). Language learning strategy use: A study of pre-service teachers in Malaysia. Retrieved from http://www.eric.ed.gov/PDFS/ED521415.pdf. 


\title{
Supporting cognitive and metacognitive learning strategies in technologically enhanced language learning
}

\author{
Katrin Saks ${ }^{\mathrm{a} 1}$, Äli Leijen ${ }^{\mathrm{a}}$ \\ ${ }^{a}$ University of Tartu, Institute of Educational Sciences
}

\section{Summary}

\section{Introduction}

The widespread use of learning technologies in different educational settings has generated the growing need for students to self-regulate their learning activities (Bannert \& Reimann, 2012). Many studies have identified a significant positive correlation between academic achievement and self-regulated learning ability (Dabbagh \& Kitsantas, 2005; Schunk \& Zimmerman, 1994). However, students rarely demonstrate adequate skills of self-regulation which in turn may prevent them from achieving satisfactory academic results (Kiewra, 2002; Lee et al., 2010). Similar deficit of self-regulated learning skills has been reported in the studies of language learning (Benson, 2011).

Self-regulated learning skills are of crucial importance to be academically successful, at the same time they seem to be one of the most complicated learning skills to acquire. As there is no single understanding of an efficient way of scaffolding self-regulation, the focus of the current study is on the introduction and assessment of the model of developing effective language learning strategies (LLSs) and self-regulative strategies in the context of language learning. We based the developing of the model on the theoretical framework of Oxford's LLSs (1990) and the theory of selfregulation by Pintrich (2000).

According to Oxford and Crookall (1989), LLSs have the features of contributing to the main goal, allowing learners to become more selfdirected, being problem-oriented, including specific actions taken by the learner, involving many aspects of the learner, not just cognitive, supporting learning both directly and indirectly, being not always observable, being conscious, possible to be taught, flexible, and influenced by a variety of factors. Oxford (1990) considered both cognitive and metacognitive

Institute of Educational Sciences, Faculty of Social Sciences and Education, University of Tartu, Salme 1a, 50103 Tartu, Estonia; katrin.saks@ut.ee 
strategies necessary for efficient language learning and so both of them are included in her framework.

Pintrich's (2000) general framework for theory and research is based on four assumptions: active, constructive assumption; potential for control assumption; goal, criterion or standard assumption; and finally, mediators between personal and contextual characteristics and actual achievement or performance. Drawing from these assumptions he defined self-regulated learning (SRL) as an active, constructive process whereby learners set goals for their learning and then attempt to monitor, regulate, and control their cognition, motivation, and behaviour, guided and constrained by their goals and the contextual features in the environment (Pintrich, 2000).

Earlier researches have provided evidence that the most efficient support for learner's self-regulation is combined metacognitive scaffolding. Metacognitive scaffolding enables to foster several aspects of SRL, including self-monitoring, strategy use and interest (Winters et al., 2008) whereas the best results are achieved by the combination of cognitive and metacognitive support. Prompting has been reported to be the most efficient intervention for supporting strategy use (Kramarski \& Michalsky, 2009; Lee et al., 2010).

In this study we used the knowledge received in the literature review on the most efficient ways of supporting learners' cognitive and metacognitive learning strategies, and designed a model to support the use of these strategies in the blended language learning course. The model (Saks \& Leijen, 2014) comprising four learning assignments provided with prompts was applied to the Tourism English course. The research questions of the current study were the following: (1) find out whether and how the learners' use of LLSs changed as a result of the intervention where the learning assignments provided with prompts were used; (2) find out whether and how the learners' use of self-regulative learning strategies changed as a result of the intervention where the learning assignments provided with prompts were used; (3) find out whether and how the learners' content knowledge improved as a result of the intervention.

\section{Methodology}

To improve the learners' use of cognitive and meta-cognitive strategies the intervention with four language learning assignments was designed and provided with prompts. The assignments were specially designed to take maximum advantage of the affordances of the digital learning environment (Moodle). Special attention was paid to students' active use of language when solving problems connected with real life situations in the 
tourism industry. Students' interaction and communication were encouraged throughout the whole learning process, as well as in preparatory and follow-up phases. All learning activities were reflected orally in the classroom, as well as in written form in students' learning diaries.

The data were collected from 28 students, 5 men and 23 women, who took the first year English for Specific Purposes, Tourism English course during a four month period. The average age of the students was 20.18, the duration of their previous English studies was approximately 10 years, the average score of the national English examination (B2) having been taken four months earlier was 75.14 points out of 100 .

The data were collected with three self-report questionnaires translated and adapted for Estonian learners - Est-SILL for LLSs, MSLQ and SRL-SRS for self-regulation. The latter was used to have a more detailed insight into learners' self-regulative processes as this instrument enables the measurement of planning, monitoring and evaluating separately. Content knowledge was assessed with the content test compiled by the first author. The test included the tasks that combined different language skills and assumed using different LLSs. The data were collected with pre- and post-tests.

\section{Results and conclusions}

Previous research has revealed that the most efficient way of supporting learners' use of cognitive and metacognitive learning strategies is their combined scaffolding with prompts (e.g. Brunstein \& Glaser, 2011; Kramarski \& Michalsky, 2010; Lee et al., 2010). On the basis of that a model and concrete assignments were developed to support learners' cognitive and metacognitive strategies. For intervention four specific language learning assignments were designed and accompanied with prompts. Prompting scaffolded strategy instruction in the classroom as well as in the digital learning environment. During designing the model it was considered necessary to provide various phases of the tasks with prompts of cognitive as well as metacognitive strategies. Students were encouraged to plan, monitor and self-evaluate their learning activities with constant discussions in the class and by supporting prompts in the web-based environment.

The results of the measurement confirmed the results of many earlier studies where combined scaffolding had proved to be efficient to support learner's use of learning strategies (Askell-Williams et al., 2012; Bannert \& Reimann, 2012; Kauffman et al., 2011; Nash-Ditzel, 2010). The results of paired samples t-tests indicated that the developed assignments supported 
with prompts promoted the usage of all more advanced LLSs, while active use of language, compensation and social strategies improved most of all (Table 3). This can be explained with the use of communicative language learning methods and the learning assignments that assumed active communication and self-expression orally as well as in written form. The only strategy group that did not show significant improvement was the one of memory strategies. According to Oxford (1990), memory strategies are mainly exploited by beginners, and usually they are replaced with more advanced strategies in further studies.

The results also showed that supporting metacognitive learning strategies in combination with cognitive ones advanced most of all learners' metacognitive self-regulation, primarily their planning and evaluating activities (Table 4). At the same time it supported learners' control of their learning beliefs which in turn helped to advance their intrinsic motivation. To support learners in the phase of monitoring, they probably need more direct support from the teacher in the form of oral prompts and instruction.

The results of the content test indicated that the assignments prompting learners' use of cognitive and metacognitive learning strategies assist gaining content knowledge and language skills, and also support learners' selfexpression in English. The combined assignments included in the content test revealed the learners' ability to apply new knowledge and skills, and express them verbally in English.

Our findings are in line with the conclusion that the combination of cognitive and metacognitive scaffolding accompanied with prompts is a vehicle for promoting learners' self-regulation and better learning gains (Bannert \& Reimann, 2012; Berthold et al., 2007; Brunstein \& Glaser, 2011; Kramarski \& Gutman, 2006; Kramarski \& Michalsky, 2009, 2010). The present study also calls for further scrutiny of supporting learners' monitoring activities.

Keywords: language learning strategies, self-regulation, content knowledge, blended language learning course, self-report questionnaire 